影や婦人科の骨盤計测などの低線量撮影には，より撮影線量を低減 した撮影を行うことができ，被曝線量の低減に期待ができる。また

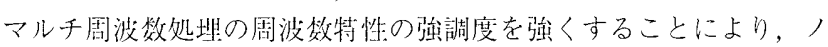
イズ特性の劣化による限界があったが，上り強い強調度を遙択で き，臨床写真の画質の向上の可能性が考えられる。

$110 \mathrm{~S} / \mathrm{N}$ 改善処理を肘いたCR-Mammographyの検討 日本医科大学付属干葉北総病院·中央画像検査室 田村 京, 渡辺典男 丸山智之，菅沼一男，川村義彦

日本医科大学千葉北総病院・放射線科 岡田 進

【目的】当院では乳房撮影にCRシステムを用いている。CRシステム なとのディジタル系検出器は各種画像処理ができ, 広いダイナミッ クレンジ，高コントラスト分解能を有するなどの利点があるが，解 像特性やノイズの影響でS/Fシステムに劣るとされている。特に Dense Breastなどではノイズの影響が目立ち不灰化との分別がつきに くい，そこで今回開発されたFCRのS/N改善処理を，皆来臨床て使用 しているパラメーターに侻用することでの画像の評俩を臨床画像と ファントム画像で行ったので報告する。

【方法】画像の評伴にはROCを用いた。評価は以下の 2 垻目で行っ た.1）通常の撮影を行った臨床の画像とその画像にS/N改善処理を 用いた画像。2)自作乳房ファントムに擬似不灰化を配置し噪床条件 で撮影，オリジナル処理， $+\mathrm{S} / \mathrm{N}$ 改善処理，+石灰化強調処理の面 像。使用装犆は鳥津製作所SEPIO，CRはFCR9000システム，IPは HR-Vを用いた.

【結果と考察】今回 $S / N$ 改善処埋を従来の画像に併用することでDense Breastの乳腺内構造の分離が現状より改善された，微紐石灰化の描 出はS/N改善処理と他のパラメーターゃ石灰化强調処理との併用に より向上する可能性もあり今㣪十分期待できるものと思われる。

\section{$111 \mathrm{CR}$ 骨撮影画像に対するノイズ抑制处理の棓㑜} 大阪医科大学附属病院・放射線科 西端豊, 濱田松治, 漢那憲聖 楢林 勇

\section{富士写真フイルム(株) 小川英二}

【目的】X線画像に扔いては，撮影線量が减少するにつれ西像中の， イズ成分が譄加し粒状の悪い画像となる。今回富上写真フイルム (怢)より有效信昂を低下させず粒状を改善する為にノイズ成分を選 択的に抑制する「ノイズ抑制処理」ソフトが開発され，それを使用す る機会が得られたので，霄撮影に対して画像の評価を行った。

【方法】サンプルはさまざまな骨撮影画像に対して，現在当院で愺用 している画像とノイズ抑制処理使用での富士推奖画像，それと当施 没で恰討した画像の3枚をセットとし，整形外科医数名が評価を行 う.

【結果】ノイズ抑制処理ソフトを使用することにより，粒状の悪い画 像からノイズ成分を抑制し，画像の问上が行えた。また整形外科医 の評们に拈いてもノイズ抑制処理は有用であり，臨床的価值を見出 せた。

【考察】ノイズ抑制処理後の画像に対し従来の画像処埋の強調度を強 くすることで，信号成分を效率的に强調することが可能となり，よ り診断能の高い画像を形成できる可能性がある。しかしノイズの抑 制度が強すざるとボケた印象となるため注意が必要である。ノイズ 抑制処理は使い方を鿁ると郖床笑から䛨価が得られなくなることも 考えられるが，新たなる洒值を生む可能性をを柲めておりさらに検討

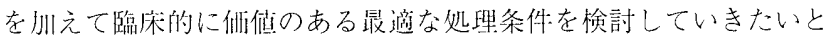
考える。
112 オンラインFCR-DICOM画像を用いた冓柱長尺撮影像の画像 処理.

大阪大学医学部附属病院 放射線部 山本修司，川本清澄，小水 満 大阪大学大学院・医学系研究科生体制御工学講座 友田 要 大阪大学大学院医学系研究科医用物理学講座 上申 剛

【目的】本学において新しく㽬入されたFCR用のQA-Workstationを用 いて, 従来の煩雑な脊柱唇尺撮影の後処埋をオンラインにで效率的 に画像処埋をするシステムを考案したので報告する。

【使用穖器上方法】従来の木学に扔けるFCRネ・トワークシステムに 加え，蒚士フフイル社製FCR-QA-Workstation (HI-C655QA, Fujı Film Co)が導入され, 沉用のWIndows OS上で, 效率的に非非緗のDICOM 画像を取得することが可能となった。このシステムを胿いて，㝓柱 長尺像の 2 枚の画像を連結し, 画像全体のゲインコントロール処理 を施し，その垂直投影変換によって得られるプロファイルの不速続 点となるエッジ部の直前のピクセルを慗ぐことによって2枚の函像

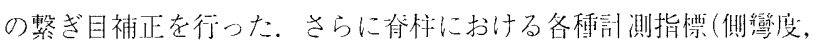
Wedge Angle) 在行うための倠休执よびその特徽点抽出法在佮討し た。本処理における開発噮㑽は，主にMatlab(Cybernet.Co) および IDL (Adamnet.Co)を用いた。

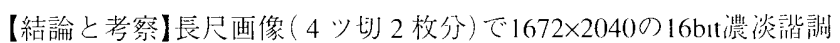

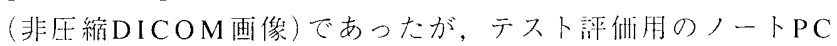
(PentiumIII 800-MHz，524Mbite-Memory)でもほぼ,リアルタイムな 画像処埋が可能であった。計測処理と二次元の形態情能の收得のみ を目的とする場合は，等倍のフィルム出力から手作業で写真の斯り 付けや計測処理をする場合に此べて，計測結果と画像だけを縮小し

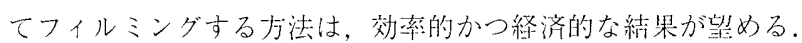

113 ドライフィルムの保存性に関する研究一大服府下多施設の検 討 -

大阪府下公立病院・放射線技師会研究委員会

東大阪市立総合病院 木村龍太郎

箕面市立病院 善積 透，松浦 隆，吉住哲彦

市立豊中病院 蓦西立史，市村叔照

市立池田病院 宇戸朋之

市立枚方市民病院 穴井達弥

岸和田市民病院＼cjkstart増成豊和，瀬戸嶋剛

市立堺病院 赤阪真由美, 藤本 学

和泉市立病院 奥田秀憲

\section{市立泉佐野病院 田原大世, 常玄大輔}

【背景・目的】近年，イメージャのドライ化は作業噮境の簡素化や噮 境閣題の点から备施設に扔いて推進さ机ている。われわれは，第56 回の木総会においてドライフィルムの保有性として备社フィルムの 濃度変化に対して検討を行った。現在, 前回から 4 年が経過し各社. から新たに保存性が改食されたフィルムが発売されている。よって 本研究ではこれら新しいフィルムに対し，大阪府下の多施榄で同帱 期に各フィルムの保倍性について倹討を行った。

【方法】各レーザーイメージャよりSMPTEのフイルム出力を行い, 出 カ後のフィルムに対し各社推掊条件, 各施設でのフィルム保管: 条 件, 温度, 湿度, 光の負荷を連続的に与えた状態で保存を行い, 各 フィルムの経時的な濃度変化について検討を行った。

【結果および考察】今回の娭討では，ドライフィルムは各祄の推奖条 件，各施設でのフィルム保管条件で保存する限りは，奏使朋上润题 がないことが再度確認された。しかし，推奖条件外の保存条件では 各フィルムにおいて濃度変化が発生した。この濃度変化の割合は湿 度, 湿度, 光に対する変化が各社で異なり, 只の程度は备フィルム の濃度帯域でも変化が異なる事が確認された。また，この程度は過 去の報告(第56回総会) 時より各社とも改善されたものの, 实使用上: 十分に满足行くものではなく，われわれ使用者はドライフィルムの 